\title{
Seasonal variation of airborne fungal propagules indoor and outdoor of domestic environments in Mérida, Mexico
}

\author{
C. PONCE-CABALLERO, M. GAMBOA-MARRUFO, M. LÓPEZ-PACHECO, I. CERÓN-PALMA, \\ C. QUINTAL-FRANCO, G. GIÁCOMAN-VALLEJOS and J. H. LORÍA-ARCILA \\ Facultad de Ingeniería, Universidad Autónoma de Yucatán. Av. Industrias no Contaminantes por Anillo Periférico \\ Norte S/N, apartado postal 150 Cordemex, Mérida, Yucatán, México \\ Corresponding author: C. Ponce-Caballero; e-mail: cponce@uady.mx
}

Received January 5, 2012; accepted February 6, 2013

\begin{abstract}
RESUMEN
El objetivo de este estudio fue establecer la variación estacional de propágulos fúngicos en ambientes interiores y exteriores de casas habitación en Mérida, México. Asimismo, este estudio examina la relación entre el número de propágulos fúngicos en ambientes interiores y exteriores con parámetros ambientales como temperatura, humedad y velocidad del viento. El muestreo se realizó durante los periodos de secas (mayo), lluvias (octubre) y frentes fríos (febrero) en el interior y exterior de viviendas. Las medias geométricas de la concentración de propágulos fúngicos interiores y exteriores fueron de 1653 y $1432 \mathrm{UFC} / \mathrm{m}^{3}$ durante los frentes fríos, de 125 y $92 \mathrm{UFC} / \mathrm{m}^{3}$ durante el periodo de secas y de 1326 y $1145 \mathrm{UFC} / \mathrm{m}^{3}$ durante el periodo de lluvias, respectivamente. La fracción respirable se incrementó de 50 a 100\%. La composición de géneros fúngicos exhibió una variación estacional: se identificaron 19 géneros durante los tres periodos, entre los que se encuentran principalmente Cladosporium spp., Penicillium spp., Aspergillus spp., Fusarium spp. y Acremonium spp. La concentración de propágulos fúngicos y la heterogeneidad encontrada en Mérida fueron análogas a las detectadas en estudios similares en otras ciudades con clima tropical húmedo. Este estudio concluye que la concentración de propágulos fúngicos y su fracción respirable pueden vincularse con varios factores del medio ambiente, principalmente con la humedad relativa.
\end{abstract}

\begin{abstract}
The aim of this study was to establish the seasonal variation of fungal propagules in homes of Mérida, Mexico, and to examine the relation between their concentrations in enclosed and open locations taking into account environmental parameters such as temperature, humidity and wind speed. Samples were taken inside and outside domestic environments during the most characteristic weather seasons in the region: dry season (sampled in May), rainy season (sampled in October), and cold fronts season (sampled in February). The geometric mean of the indoors and outdoors concentration of airborne fungal propagules was 1653 and $1432 \mathrm{CFU} / \mathrm{m}^{3}$ during the cold fronts period, 125 and $92 \mathrm{CFU} / \mathrm{m}^{3}$ during the dry period, and 1326 and $1145 \mathrm{CFU} / \mathrm{m}^{3}$ during the rainy period. The respirable fraction during the three periods sampled was always within a range of 50 to $100 \%$. The composition of fungal genera exhibited a seasonal change, and 19 of these were identified. The main genera found during the three periods were Cladosporium spp., Penicillium spp., Aspergillus spp., Fusarium spp., and Acremonium spp. The fungal aerosol concentrations and diversity found in Mérida, Mexico, were similar to those from other reports of cities with comparable tropical humid climate. This study concludes that the concentration of airborne fungal propagules and its respirable fraction can be related to several meteorological factors, mainly to relative humidity.
\end{abstract}

Keywords: Bioaerosols, fungal propagules, interior environment air, humidity stains, environmental factors. 


\section{Introduction}

The environment contains naturally fungi, which are an important factor for the decomposition of organic matter. However, in interior spaces, fungi could be an important factor in human pathology (Carrer et al., 2001; Mendell et al., 2011). These microorganisms may affect human health in several ways. The possible human reactions are allergies (sensitization and immune response [e.g., asthma, allergic rhinitis or hypersensitivity pneumonitis]), infections (fungal infections [e.g., aspergillosis]) and toxic responses (Husman, 1996; Gorny et al., 2002).

Epidemiologic research has shown that these diseases are frequently associated with exposure to large amounts of fungal spores in the air (Mendell et al., 2011). However, infectious diseases caused by inhalation of different fungi depend not only on the number of spores inhaled, but also on the site of deposition in the respiratory system, which is directly related to the aerodynamic diameter of the particle (fungal spore). Particles smaller than $5 \mu \mathrm{m}$ (the socalled respirable fraction) are able to penetrate into the alveoli and can lead to allergic alveolitis and other serious illnesses (Pastuszka et al., 2000).

The concentrations of fungal spores in the outdoor air may vary greatly depending on the weather and the climate. Generally, outdoor air is the dominant source of indoor fungi. Many fungal spores are transported across great distances and are also regularly found indoors. The fungal spores enter a building through outdoor air intakes (e.g., the air conditioning systems, doors and windows), and as contaminants on building materials and contents (Shelton et al., 2002).

In homes with adequate thermal insulation, moisture control and healthy room conditions, fungal spores normally have no chance to colonize. Indoor spaces that have low humidity and characteristic air movements as a result of heating and natural ventilation do not provide favorable conditions for the survival of fungi. In cases of high humidity, however, fungi may grow on almost all organic substrates. Pasanen $e t$ al. (1991) found that temperatures between $21-30{ }^{\circ} \mathrm{C}$ and relative humidities higher than $75 \%$ could induce faster fungal germination and growth. Therefore, it is considered that fungi grow much easier in areas with humid-warm climate. The city of Mérida in Yucatán, Mexico is characterized by a humid-warm climate with annual mean temperature of $25.2^{\circ} \mathrm{C}$ and mean relative humidity of $70 \%$ (Conagua, 2000).
In this context, the aim of this study was to establish, for Latin-American affordable housing in tropical climate, the seasonal variation of fungal propagules indoor and outdoor of domestic environments; to evaluate the existing relation between the number of colony-forming units (CFU) and its corresponding respirable fraction considering the environmental conditions at the moment of sampling; and to establish an equation to help predicting indoors CFU concentrations using a multiple regression analysis.

\section{Materials and methods}

\subsection{Sampling sites}

The air samples were collected during the months of February, April and October 2008 within the most characteristic weather seasons in the region: the cold fronts period, and the dry and rainy seasons, respectively. Samples were taken between 10:00 and 14:00 LT in the living room from houses built one to three years before this study, in a residential neighborhood (affordable housing) located at the northern section of the city of Mérida in the state of Yucatán, Mexico. Thirty houses were selected on the basis of interest shown by the residents to participate in the study; all of these were sampled during the cold fronts season, but only 27 were sampled during the dry season and 24 during the rainy season. All selected houses presented the same type of construction (kind of windows and building materials); however, some of them were two stories high, had different orientation and history of previous moisture damage (with and without mold problems). None of the houses had air conditioning system in the room where the sampling was carried out but all of them had ceiling fans.

\subsection{Indoors and outdoors fungal propagules}

Air samples were collected inside and outside of the homes, using the six-stage Andersen impactor model 10-709 1 ACFM, with aerodynamic cut-size diameters by level of 7, 4.7, 3.4, 2.1, 1.1, and 0.65 $\mu \mathrm{m}$ (Andersen Instruments Inc.). Stages 2 to 6 were used to obtain the respirable fraction (diameters between 4.7 and $0.65 \mu \mathrm{m}$ ). Culturable airborne fungal propagules were collected on Petri dishes with malt extract agar (MEA), a solid general-purpose media for cultivation of fungi and yeast, with $0.1 \mathrm{~g} / \mathrm{L}$ of novobiocin to inhibit bacterial growth. The equipment 
was located at a natural breathing height of $1.5 \mathrm{~m}$, and sampling periods were of 4 to $5 \mathrm{~min}$, withdrawing air at a flow rate of $28.3 \mathrm{~L} / \mathrm{min}$.

\subsection{Sample analysis}

After air sampling, the petri dishes were incubated for three days at room temperature (approximately $26^{\circ} \mathrm{C}$ ) for counting CFUs. The total culturable fungal aerosol concentration was determined by dividing the corrected colony count (using the positive-hole correction) by the volume of air sampled and was reported as colony forming units per cubic meter of air $\left(\mathrm{CFU} / \mathrm{m}^{3}\right)$. The positive-hole correction is used to take into account the probability of particles going into empty holes on a given petri plate while sampling is carried out (Andersen, 1958). The genera of fungi were identified after incubating for 28 days based upon their micro- and macro-morphological characteristics, using standard taxonomic keys (De Hoog et al., 2000; Barnett and Hunter, 1998; Dugan, 2006).

\subsection{Environmental parameters}

Simultaneously to the air sampling, meteorological data (temperature and relative humidity) were record- ed with an indoor air quality Quest Temp data-logging monitor (Quest Technologies Corp.).

\subsection{Statistical analysis}

Descriptive statistics, including minima, maxima, geometric means and medians were used for the data analysis. The correlation coefficients for different parameters were calculated using simple linear regression models. A multiple regression analysis of seven independent variables with forward selection was carried out aiming to obtain an equation that would help to predict the concentration of fungal aerosols inside the houses. The independent variables were external CFU concentration, internal and external temperature, relative humidity, and wind speed. All the statistical analyses were made using two statistical software programs: the Statistical Package for the Social Sciences (SPSS) 13.0 for Windows and Statgraphics Plus 5.1 for Windows.

\section{Results and discussion}

\subsection{Bioaerosols respirable fraction}

The concentration of fungal propagules found during the three characteristic weather seasons in the region is shown in Table I. During the cold fronts season the

Table I. Indoor and outdoor fungal propagules concentrations $\left(\mathrm{CFU} / \mathrm{m}^{3}\right)$ in different weather seasons.

\begin{tabular}{|c|c|c|c|c|c|c|c|c|c|c|c|c|c|}
\hline \multirow{2}{*}{\multicolumn{2}{|c|}{ Weather season }} & \multicolumn{4}{|c|}{ Indoors } & \multicolumn{4}{|c|}{ Outdoors } & \multicolumn{4}{|c|}{ Indoors/outdoors } \\
\hline & & $\dot{\Xi}$ & $\stackrel{\dot{x}}{\dot{\Xi}}$ & 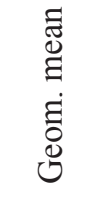 & 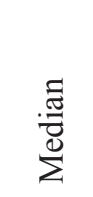 & $\dot{\Xi}$ & $\sum^{\stackrel{x}{a}}$ & 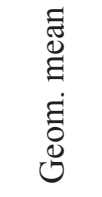 & 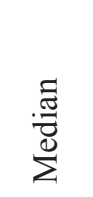 & $\dot{\Xi}$ & $\sum^{\dot{x}}$ & 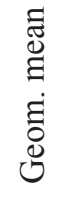 & 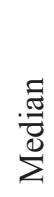 \\
\hline Cold fronts $(n=3$ & & & & & & & & & & 0.2 & 7.5 & 1.2 & 1.1 \\
\hline Total fungi & $\left(\mathrm{CFU} / \mathrm{m}^{3}\right)$ & 268 & 7757 & 1653 & 1772 & 125 & 4607 & 1432 & 1576 & & & & \\
\hline Respirable fungi $^{\mathrm{a}}$ & $\begin{array}{l}\left(\mathrm{CFU} / \mathrm{m}^{3}\right) \\
(\%)\end{array}$ & $\begin{array}{r}250 \\
91\end{array}$ & $\begin{array}{r}7279 \\
99\end{array}$ & $\begin{array}{r}1559 \\
94\end{array}$ & $\begin{array}{r}1668 \\
95\end{array}$ & $\begin{array}{l}98 \\
79\end{array}$ & $\begin{array}{r}4375 \\
98\end{array}$ & $\begin{array}{r}1342 \\
94\end{array}$ & $\begin{array}{r}1424 \\
95\end{array}$ & & & & \\
\hline $\begin{array}{l}\text { Dry }(n=27) \\
\text { Total fungi } \\
\text { Respirable fungi }{ }^{a}\end{array}$ & $\begin{array}{l}\left(\mathrm{CFU} / \mathrm{m}^{3}\right) \\
\left(\mathrm{CFU} / \mathrm{m}^{3}\right) \\
(\%)\end{array}$ & $\begin{array}{l}18 \\
18 \\
69\end{array}$ & $\begin{array}{r}1254 \\
1254 \\
100\end{array}$ & $\begin{array}{r}125 \\
110 \\
88\end{array}$ & $\begin{array}{r}107 \\
89 \\
90\end{array}$ & $\begin{array}{l}36 \\
18 \\
50\end{array}$ & $\begin{array}{l}507 \\
498 \\
100\end{array}$ & $\begin{array}{l}92 \\
85 \\
88\end{array}$ & $\begin{array}{l}80 \\
80 \\
92\end{array}$ & 0.3 & 35.3 & 1.3 & 1.0 \\
\hline $\begin{array}{l}\text { Rainy }(n=24) \\
\text { Total fungi } \\
\text { Respirable fungi }^{\text {a }}\end{array}$ & $\begin{array}{l}\left(\mathrm{CFU} / \mathrm{m}^{3}\right) \\
\left(\mathrm{CFU} / \mathrm{m}^{3}\right) \\
(\%)\end{array}$ & $\begin{array}{r}267 \\
258 \\
93\end{array}$ & $\begin{array}{r}6308 \\
5988 \\
100\end{array}$ & $\begin{array}{r}1326 \\
1280 \\
97\end{array}$ & $\begin{array}{r}1206 \\
1161 \\
97\end{array}$ & $\begin{array}{r}258 \\
214 \\
83\end{array}$ & $\begin{array}{r}8657 \\
8443 \\
100\end{array}$ & $\begin{array}{r}1145 \\
1091 \\
95\end{array}$ & $\begin{array}{r}921 \\
885 \\
96\end{array}$ & 0.6 & 8.8 & 1.2 & 1.0 \\
\hline
\end{tabular}

${ }^{a}$ Culturable fungal particles with aerodynamic diameter $<5 \mu \mathrm{m}$.

Min: minimum; Max: maximum; Geom. mean: geometrical mean; $n$ : number of homes sampled; \%: respirable fungi/ total fungi in each house. 
geometric means were 1653 and $1432 \mathrm{CFU} / \mathrm{m}^{3}$ at indoor and outdoor environmental air, respectively; while during the dry season they were $125 \mathrm{CFU} / \mathrm{m}^{3}$ indoors and $92 \mathrm{CFU} / \mathrm{m}^{3}$ outdoors. During the rainy season the geometric means of these concentrations were 1326 and $1145 \mathrm{CFU} / \mathrm{m}^{3}$, respectively. The respirable fungal particles found during all seasons were between 50 to $100 \%$ of the total fungal concentrations.

The total concentrations of fungal propagules outdoors showed no significant differences with its corresponding concentrations indoors in each season. Also, the only significant difference between seasonal concentrations of fungal propagules was found between the dry and the other two seasons $(P<0.05)$. Between the rainy season and the period of cold fronts there were no significant differences.

\subsection{Fungal aerosols indoor/outdoor ratios (I/O)}

The indoor/outdoor ratios (I/O) for fungal aerosols are also shown in Table I. These I/O ratios for the cold fronts season were between 0.2 and 7.5 with a median of 1.1. For the dry season, the fungal aerosols $\mathrm{I} / \mathrm{O}$ ratios median value was 1.0 , with a range from 0.3 to 35.3 . For the rainy season, these $\mathrm{I} / \mathrm{O}$ ratios were between 0.6 and 8.8 , and their median was also 1.0.

The I/O ratios obtained for fungal aerosols varied from house to house in the sample, but the mean values were not different amongst seasons. Therefore, most of the ratio values obtained for all seasons were near 1 . This value indicates a balance between the particles found indoors with those found outdoors, possibly due to natural ventilation conditions existing in all the houses (lack of air conditioning systems). Higher indoor concentration levels and variability in the $\mathrm{I} / \mathrm{O}$ ratios observed for airborne fungi in seven houses may be associated with indoor sources. These indoor sources may be related to lack of proper ventilation, which increases the humidity indoors. The $\mathrm{I} / \mathrm{O}$ ratios $<1$ may be related with partial penetration of airborne fungal propagules from outdoor to indoor environment.

Peculiarly, the maximal I/O ratio (35.3) occurred in a house where the residents reported no visible mold problems. The indoor concentration in this house could be influenced by the construction activities outdoors in the surroundings of the sampling point.

\subsection{Fungal propagules heterogeneity}

An important consequence of air microbial contamination consists on the possibility of being exposed to high fungal-spore concentrations, increasing the risk of asthma and diverse respiratory syndromes. Nevertheless, asthma and allergic rhinitis are not only caused by exposure to high concentrations of aerosols; another important factor in the development of the disease is the type of spores to which they are exposed. Ege et al. (2011) found that the microbial exposure levels indoors was less important than the composition and diversity, therefore, exposure to different fungal or microbial profiles may produce different health effects.

Figures 1 and 2 show the main fungi genera found in indoor and outdoor air. We identified 19 fungal genera in total; 18 and 16 were found during the dry and cold fronts seasons, respectively; while during the rainy season only 11 fungal genera were present. The main fungal genera found during the three seasons were Cladosporium spp., Penicillium spp., Aspergillus spp., Fusarium spp., and Acremonium spp. However, Absidia spp. and Trichophyton spp. were found during the cold fronts season only, while Botrytis spp., Chaetomium spp., Malassezia spp., Memnoniella spp., and Nigrospora spp. were present only during the dry season.

Future research is necessary to examine thoroughly the effects of bioaerosols exposition in health problems. However, Cladosporium fungal spores, as well as Alternaria, Aspergillus, and Penicillium have been frequently found in patients with chronic sinusitis (Shin et al., 2007) and are classified as allergenic fungi (Gómez de Ana et al., 2007).

The main fungi genera identified in this work are similar to those found in countries with diverse weather conditions, where members of Cladosporium spp. were predominant, e.g., Lee and Jo (2006) in Korea, Lis et al. (1997) in Poland, Pei-Chih et al. (2000) in Taiwan and Takahashi (1997) in Japan.

\subsection{Environmental factors}

Humidity and temperature are well known as the main environmental factors that influence the development of fungi; therefore, they were monitored. The results are shown in Table II.

During the cold fronts season relative humidity varied from 30 to $69 \%$ outdoors and from 35 to $77 \%$ indoors; during the dry season, from 22 to $72 \%$ and from 31 to $73 \%$, respectively. During the rainy season, 


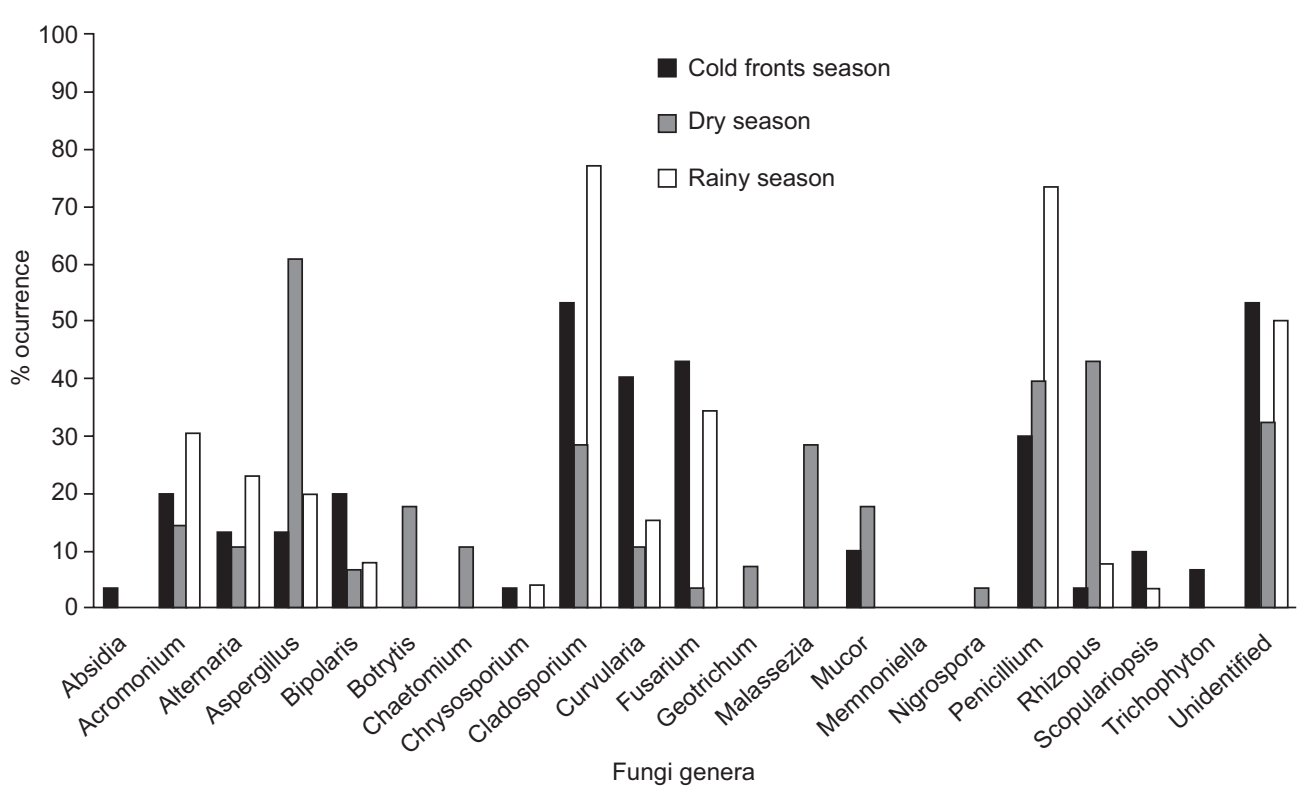

Fig. 1. Airborne culturable fungal genera isolated from indoor environments during the three characteristic weather seasons.

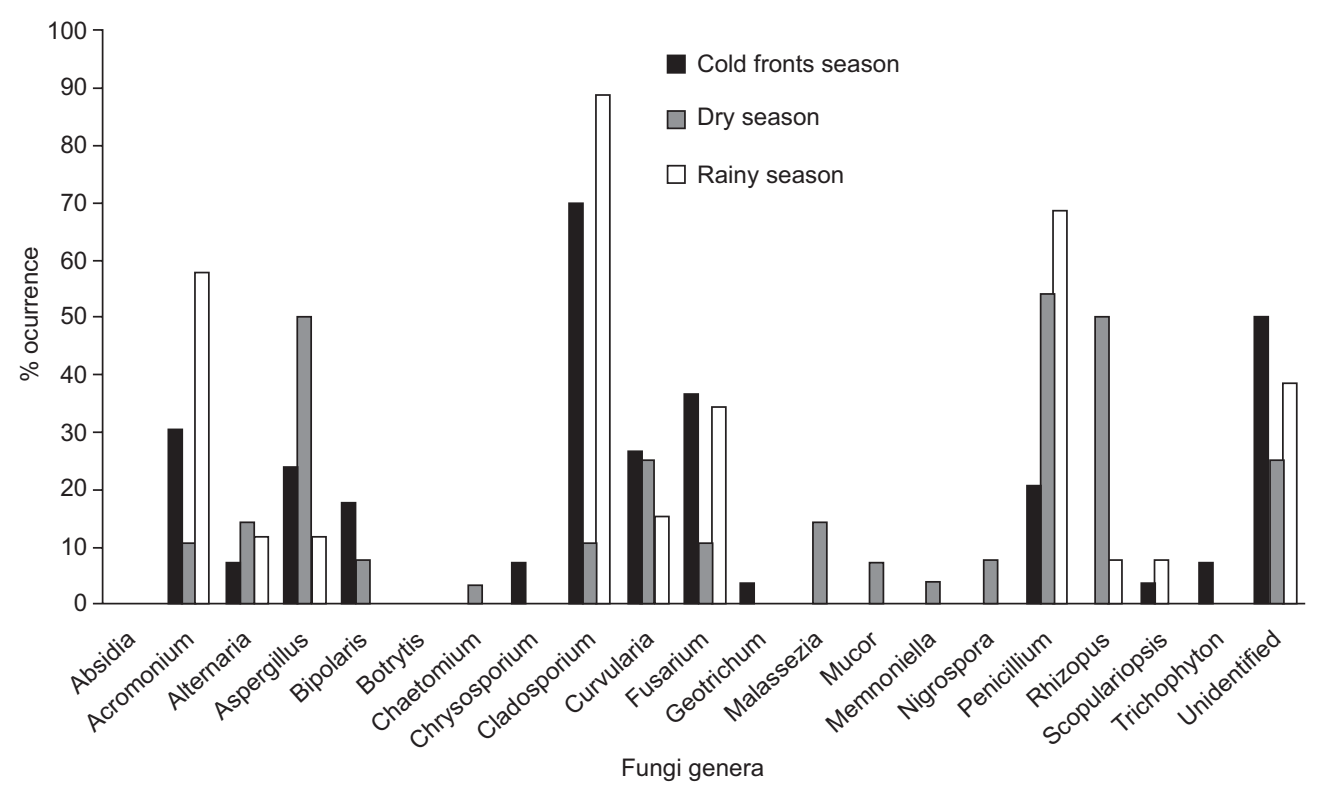

Fig. 2. Airborne culturable fungal genera isolated from outdoor environments during the three characteristic weather seasons.

relative humidity varied from 38 to $68 \%$, and from 46 to $78 \%$, outdoors and indoors, respectively. The composition of fungal aerosols also exhibited a seasonal variation according to the climatic conditions of the area. Temperatures ranged between 25 and $38^{\circ} \mathrm{C}$, from 27 to $41{ }^{\circ} \mathrm{C}$ and from 25 to $33^{\circ} \mathrm{C}$ during the cold fronts, dry and rainy seasons, respectively.
3.5 Relationship between airborne fungal propagules and environmental factors

The correlation coefficients between total airborne fungal propagules and its respirable fraction indoors and outdoors, as well as the correlation coefficients amongst the diverse environmental factors analyzed, are shown in Figure 3. 
Table II. Statistics of environmental indoor- and outdoor-air parameters.

\begin{tabular}{|c|c|c|c|c|c|c|c|c|c|}
\hline \multirow{2}{*}{$\begin{array}{l}\text { Weather season/ } \\
\text { parameters }\end{array}$} & & \multicolumn{4}{|c|}{ Indoors } & \multicolumn{4}{|c|}{ Outdoors } \\
\hline & & Min. & Max. & $\begin{array}{c}\text { Geom. } \\
\text { mean }\end{array}$ & Median & Min. & Max. & $\begin{array}{c}\text { Geom. } \\
\text { mean }\end{array}$ & Median \\
\hline \multicolumn{10}{|c|}{ Cold fronts $(n=30)$} \\
\hline Temperature & $\left({ }^{\circ} \mathrm{C}\right)$ & 25.2 & 36 & 30.3 & 29.5 & 24.9 & 38 & 30.7 & 30 \\
\hline Relative humidity & $(\% \mathrm{RH})$ & 35 & 77 & 52.6 & 53 & 30.8 & 69 & 48.8 & 50 \\
\hline \multicolumn{10}{|l|}{ Dry $(n=27)$} \\
\hline Temperature & $\left({ }^{\circ} \mathrm{C}\right)$ & 27.8 & 41.1 & 34.4 & 34.3 & 27.9 & 41.6 & 34.6 & 36.1 \\
\hline Relative humidity & $(\% \mathrm{RH})$ & 31.3 & 73 & 47.0 & 47.3 & 22.7 & 72.1 & 41.5 & 42 \\
\hline \multicolumn{10}{|l|}{ Rainy $(n=24)$} \\
\hline Temperature & $\left({ }^{\circ} \mathrm{C}\right)$ & 25.1 & 33.3 & 29.1 & 29 & 25.6 & 33 & 31.0 & 30.8 \\
\hline Relative humidity & $(\% \mathrm{RH})$ & 46 & 78 & 60.8 & 62 & 38 & 68 & 52.6 & 51 \\
\hline
\end{tabular}

Min: Minimum; Max: Maximum; Geom. mean: Geometrical mean; $n$ : number of homes sampled.

Environmental temperature is reported by several authors as the main environmental factor related to the amount of bioaerosols in the air (Li and Kendrick, 1995; Jones and Harrison, 2004). Nevertheless, in this study temperature presents a negative correlation with the number of airborne fungal propagules in the environmental air indoors and outdoors, as well as its respirable fraction. This can be explained due to the characteristic temperate weather in Mérida, Yucatán, which does not present extreme temperatures throughout the year. The median of temperature during the sampling days was between 29 and $36^{\circ} \mathrm{C}$ for the three sampling seasons. Therefore, given that the optimal temperature for fungal growth is between 21 and $30{ }^{\circ} \mathrm{C}$ (Pasanen et al., 1991), a higher temperature presents a lower number of airborne fungal propagules.

\begin{tabular}{|c|c|c|c|c|c|c|c|}
\hline CFUI & 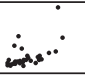 & $\rho^{\circ}$ & 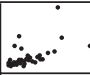 & :3ishin & سعنsid & : & 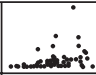 \\
\hline 0.685 & CFUO & 5 & & 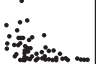 & & & \\
\hline 0.999 & 0.679 & $\mathrm{BI}$ & $\therefore 0^{\circ}$ & & & & \\
\hline 0.675 & 0.999 & 0.699 & BO & & $:$ & & \\
\hline 0.365 & -0.515 & -0.362 & -0.519 & & & & \\
\hline-0.357 & -0.422 & -0.353 & -0.419 & 0.762 & & 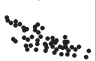 & \\
\hline 0.309 & 0.435 & 0.305 & 0.434 & 0.826 & 0.826 & & $\because v^{*}$ \\
\hline 0.344 & 0.423 & 0.339 & 0.420 & -0.778 & -0.854 & 0.854 & $\mathrm{RHO}$ \\
\hline
\end{tabular}

Fig. 3. Dispersion matrix of the different analyzed parameters and corresponding correlation coefficients (all results with $P<0.01$ for a $99 \%$ confidence interval).
In this study it can be observed that amongst the different environmental parameters, relative humidity (indoors and outdoors) was the environmental factor most related to the number of airborne fungal propagules found. The positive correlation coefficients of relative humidity with the fungal spores found, corroborates what other studies have reported regarding the importance of humidity for the development of mycelial structures of different types of fungus (Jones and Harrison, 2004).

There is a statistically significant relation between total airborne fungal propagules and its corresponding respirable fraction $(P<0.01)$; this means that the number of propagules in the environmental air (indoors or outdoors) gives an estimate of its corresponding respirable fraction. Determination of airborne fungal-propagules respirable fraction is important because this parameter assists on estimating the impact of bioaerosols on human health (Pastuszka et al., 2000). Moreover, the amount of outdoor fungal propagules is moderately related with their quantity indoors and vice versa.

Also, there is a positive correlation between indoors temperature and relative humidity with its corresponding outdoor values, this is, the values of outdoor parameters (temperature and relative humidity) would help to predict with approximately 76 to $85 \%$ accuracy the values of these parameters inside the houses. This high correlation is due to the natural ventilation and lack of insulation of the houses, which allows the easy transmission of these values from external to internal spaces. 
Table III. Regression analyses of variables.

\begin{tabular}{|c|c|c|c|c|}
\hline Variables & Regression equation & $P$ & $\begin{array}{c}\text { Adjusted } \\
r^{2}\end{array}$ & $F$ \\
\hline CFUI vs. CFUO & $\mathrm{CFUI}=265.994+1.14903^{*} \mathrm{CFUO}$ & $<0.001$ & 0.462 & 65.55 \\
\hline CFUI vs. BI & $\mathrm{CFUI}=21.7335+1.03546 * \mathrm{BI}$ & $<0.001$ & 0.999 & 119229.36 \\
\hline CFUO vs. CFUI & $\mathrm{CFUO}=587.905+0.408797 * \mathrm{CFUI}$ & $<0.001$ & 0.462 & 65.55 \\
\hline CFUO vs. BI & $\mathrm{CFUO}=602.427+0.419963 * \mathrm{BI}$ & $<0.001$ & 0.455 & 63.57 \\
\hline CFUO vs. BO & $\mathrm{CFUO}=9.75409+1.03975 * \mathrm{BO}$ & $<0.001$ & 0.999 & 125711.21 \\
\hline CFUO vs. TI & $\mathrm{CFUO}=7982.26-210.499 * \mathrm{TI}$ & $<0.001$ & 0.255 & 2599 \\
\hline BI vs. CFUO & $\mathrm{BI}=248.256+1.10027 * \mathrm{CFUO}$ & $<0.001$ & 0.454 & 63.57 \\
\hline TI vs. TO & $\mathrm{TI}=9.41903+0.692753 * \mathrm{TO}$ & $<0.001$ & 0.575 & 100.13 \\
\hline TI vs. RHO & $\mathrm{TI}=44.3714-0.265237 * \mathrm{RHO}$ & $<0.001$ & 0.600 & 110.57 \\
\hline RHI vs. TI & $\mathrm{RHI}=131.43-2.46279 * \mathrm{TI}$ & $<0.001$ & 0.678 & 155.38 \\
\hline RHI vs. RHO & $\mathrm{RHI}=11.784+0.867176 * \mathrm{RHO}$ & $<0.001$ & 0.854 & 194.04 \\
\hline
\end{tabular}

CFUI: colony forming units indoors per cubic meter; CFUO: colony forming units outdoors per cubic meter; BI: respirable fraction indoors; BO: respirable fraction outdoors; TI: temperature indoors; TO: temperature outdoors; RHI: relative humidity indoors; RHO: relative humidity outdoors.

\subsection{Multiple regression}

As Table III shows, statistically significant positive correlations of indoors CFU concentrations with diverse indoor and outdoor environmental factors were obtained. Trying to achieve an equation that would help to predict indoors CFU concentrations from seven independent variables, we carried out a multiple regression analysis using forward selection with the following indoor and outdoor environmental parameters as independent variables: colony forming units outdoors per cubic metre (CFUO); temperature outdoors (TO); relative humidity outdoors (RHO); wind speed outdoors (WSO); temperature indoors (TI); relative humidity indoors (RHI); and wind speed indoors (WSI).

The resulting equation of the adjusted model was

$$
\mathrm{CFUI}=3263.08+0.658541 * \mathrm{CFUO}-80.8659 * \mathrm{TO}
$$

with $r^{2}=0.4179$; adjusted model degrees of freedom $=2$; residual degrees of freedom $=66 ; r^{2}$ adjusted for degrees of freedom $=0.4003 ; \mathrm{P}_{\text {CONSTANT }}=$ $0.0195 ; \mathrm{P}_{\mathrm{CFUO}}=0.0000 ; \mathrm{P}_{\mathrm{TO}}=0.0487 ; \mathrm{P}_{\mathrm{ADJUSTED}}$ MODEL $=0.0000 ;$ and $\mathrm{F}_{\text {ADJUSTED MOdeL }}=23.69$.

During the multiple regression analysis the statistical parameter $r^{2}$ obtained implied that the model explains $41.79 \%$ of the CFUI (colony forming units indoors per cubic meter). The standard error of the estimate was 1333.25 CFU. This value could be used to define prediction limits for new observations. The highest $P$ value of the independent variables was 0.0487 , corresponding to the TO. Because the $P$ value is lower than 0.05 , this term is statistically significant for a $95 \%$ confidence level and therefore it is not convenient to withdraw any variables from the model.

\section{Conclusions}

As expected, the seasonal concentration of airborne fungal propagules decreased when the season changed from cold fronts to dry, and increased during the other two seasonal changes (dry to rainy and rainy to cold fronts). Of the total fungal propagules, 50 to $100 \%$ corresponded to the respirable fraction in both in- and outdoor environments. The fungal aerosol concentrations found in Mérida, Mexico, were similar to those reported for other cities with tropical humid climate. The main fungi identified in this study were similar to those found in countries with diverse weather conditions, where Cladosporium spp. were predominant.

In this study, temperature presented a negative correlation with the total and respirable fraction of airborne fungal propagule concentrations indoors and outdoors, while its correlation with relative humidity was positive. The regression model used in this study can be used in the future to predict CFUI from CFUO and TO. It can be used for typical Latin American countries with tropical climate, high humidity, and 
lack of air conditioning systems due to high costs of electricity, in homes of similar construction (affordable housing) and age (one to three years old).

The equation of the adjusted model obtained to predict CFUI was reduced from seven independent outdoor and indoor variables to only two easy achievable outdoor variables, making the prediction easier to attain. This information could be used to detect homes with indoor sources by comparing predictions with readings of higher concentrations of CFUIs, and to reduce these sources either by increasing the natural ventilation or through more costly solutions like air conditioning systems or dehumidifiers.

\section{Acknowledgements}

The research team is grateful to home residents that permitted access to their houses.

\section{References}

Andersen A. A., 1958. New sampler for the collection, sizing and enumeration of viable airborne particles. $J$. Bacteriol. 76, 471-484.

Barnett H. L. and B. B. Hunter, 1998. Illustrated genera of imperfect fungi. 4th ed. APS press, St. Paul, Minn., $218 \mathrm{pp}$.

Carrer P., M. Maroni, D. Alcini and D. Cavallo, 2001. Allergens in indoor air: environmental assessment and health effects. Sci. Total Environ. 270, 33-42.

Conagua, 2000. Normales climatológicas de Mérida, Yucatán. Periodo 1981-2000. Observatorio Sinóptico SMN-CAN, Comisión Nacional del Agua, Mexico, 1 p.

De Hoog G., J. Guarro, J. Gene and M. Figueras, 2000. Atlas of clinical fungi. Centraalbureau voor Schimmelcultures (CBS), Utrecht, The Netherlands, 1160 pp.

Dugan F. M., 2006. The identification of fungi. APS Press, Minnesota, $184 \mathrm{pp}$.

Ege M. J., M. Mayer, A. C. Normand, J. Genuneit, W. O. Cookson, C. Braun-Fahrländer, D. Heederik, R. Piarroux, E. von Mutius, S. Apprich, J. Bauer, A. Boznanski, C. Braun-Fahrländer, G. Büchele, W. Cookson, P. Cullinan, H. Danielewicz, A. Dębińska, M. Depner, M. Ege, U. Frey, O. Fuchs, J. Genuneit, D. Heederik, E. Horak, A. Hyvärinen, S. Illi, M. Kabesch, K. Kovacs, A. Kosmęda, W. Kneifel, P. Latzin, R. Lauener, G. Loss, S. J. MacNeill, M. Mayer, B. Morass, A. C. Normand, I. Noss, G. Pershagen, R. Piarroux, H. Renz, H. Rintala, M. K. Rochat, K. Schwaiger, N. Sitaridis, B. Sozanska, D. Strachan, C. Strunz-Lehner, B. Sudre, E. von Mutius, M. Waser, J. Weber and I. Wouters for the
GABRIELA Transregio 22 Study Group, 2011. Exposure to environmental microorganisms and childhood asthma. N. Engl. J. Med. 364, 701-709.

Gómez de Ana S., J. M. Torres-Rodríguez, E. Alvarado-Ramírez, S. Mojal-García and J. Belmonte-Soler, 2007. Seasonal distribution of Alternaria, Aspergillus, Cladosporium and Penicillium species isolated in homes of fungal allergic patients. J. Investig. Allergol. Clin. Immunol. 16, 357-363.

Gorny R. L., T. Reponen, K. Willeke, D. Schmechel, E. Robine, M. Boissier and S. A. Grinshpun, 2002. Fungal fragments as indoor air biocontaminants. Appl. Environ. Microbiol. 68, 3522-3531.

Husman T., 1996. Health effects of indoor-air microorganisms. Scand. J. Work Environ. Health 22, 5-13

Jones A. M. and R. M. Harrison, 2004. The effects of meteorological factors on atmospheric bioaerosol concentrations-a review. Sci. Total Environ. 326, 151-180.

Lee J. H and W. K. Jo, 2006. Characteristics of indoor and outdoor bioaerosols at Korean high-rise apartment buildings. Environ. Res. 101, 11-17.

Li D. W. and B. Kendrick, 1995. A year-round study on functional relationships of airborne fungi with meteorological factors. Int. J. Biometeorol. 39, 74-80.

Lis D. O., J. S. Pastuszka and R. L. Górny, 1997. The prevalence of bacterial and fungal aerosol in homes, offices and ambient air of Upper Silesia. Preliminary results. Rocz. Panstw. Zakl. Hig. 48, 59-68.

Mendell M. J., A. G. Mirer, K. Cheung, M. Tong and J. Douwes, 2011. Respiratory and allergic health effect of dampness, mold, and dampness-related agents: a review of the epidemiologic evidence. Environ. Health Perspect. 119, 748-756.

Pasanen A. L., O. Kalliokioski, P. Pasanen, M. J. Jantunen and A. Nevalainen, 1991. Laboratory studies on the relationship between fungal growth and atmospheric temperature and humidity. Environ. Int. 17, 225-228.

Pastuszka J. S., U. K. Tha-Paw, D. O. Lis, A. Wlazlo and K. Ulfig, 2000. Bacterial and fungal aerosol in indoor environment in Upper Silesia, Poland. Atmos. Environ. 34, 3833-3842.

Pei-Chih W., S. Huey-Jen and L. Chia-Yin, 2000. Characteristics of indoor and outdoor airborne fungi at suburban and urban homes in two seasons. Sci. Total Environ. 253, 111-118.

Shelton B. G., K. H. Kirkland, D. Flanders and G. Morris, 2002. Profiles of airborne fungi in buildings and outdoor environments in the United States. Appl. Environ. Microbiol. 68, 1743-1753. 
Shin S. H., M. K. Ye and Y. H. Lee, 2007. Fungus culture of the nasal secretion of chronic rhinosinusitis patients: seasonal variations in Daegu, Korea. Am. J. Rhinol. 21, 556-559.
Takahashi T., 1997. Airborne fungal colony-forming units in outdoor and indoor environments in Yokohama, Japan. Mycopathologia. 139, 23-33. 